\title{
Resistance of Tomato and Pepper to T3 Strains of Xanthomonas campestris pv. vesicatoria Is Specified by a Plant-Inducible Avirulence Gene
}

\author{
Gustavo Astua-Monge, ${ }^{1}$ Gerald V. Minsavage, ${ }^{1}$ Robert E. Stall, ${ }^{1}$ Michael J. Davis, ${ }^{2}$ Ulla Bonas, ${ }^{3}$ \\ and Jeffrey B. Jones ${ }^{1}$ \\ ${ }^{1}$ Department of Plant Pathology, University of Florida, Gainesville 32611, U.S.A.; ${ }^{2}$ Department of Plant \\ Pathology, University of Florida, Tropical Research and Education Center, Homestead 33031, U.S.A.; \\ ${ }^{3}$ Institut für Genetik, Martin-Luther-Universität, 06099 Halle, Germany \\ Accepted 18 May 2000.
}

\begin{abstract}
Tomato race 3 (T3) of Xanthomonas campestris pv. vesicatoria $(\mathrm{Xcv})$ elicits a hypersensitive response $(\mathrm{HR})$ in leaves of Lycopersicon esculentum near-isogenic line (NIL) 216 and pepper genotypes. One cosmid clone (35 kb) selected from a genomic library of a T3 strain induced an HR in all resistant plants. A $1.5-\mathrm{kb}$ active subclone containing the putative avirulence (avr) gene, designated $a v r X v 3$, was sequenced. The $a v r X v 3$ gene encodes a 654-bp open reading frame (ORF) with no homology to any known gene. Expression studies with a fusion of this gene and uidA indicated that $a v r X v 3$ is plant inducible and controlled by the hypersensitivity and pathogenicity (hrp) regulatory system. Mutational analysis and transcription activation assays revealed that AvrXv3 has transcription activation activity in yeast, and that the putative domain responsible for that activity is located at the C terminus of the AvrXv3 protein. Agrobacterium tumefaciens-mediated transient expression confirmed the direct role of AvrXv3 in eliciting the HR in tomato NIL 216 and supported the hypothesis that Avr proteins must be present inside the plant host cell to trigger the HR.
\end{abstract}

The gene-for-gene model, proposed by Flor in the 1940s, suggested the existence of an incompatibility system between plants and pathogens controlled by single dominant genes (Flor 1971). In this model, the interaction between a pathogen expressing an avirulence (avr) gene product and a host expressing the appropriate resistance $(R)$ gene product results in cell death and limited spread of the pathogen (Bent 1996).

Minsavage et al. (1990) demonstrated the gene-for-gene relationship for Xanthomonas campestris pv. vesicatoria $(\mathrm{Xcv})$ in pepper and tomato, and identified three different groups among Xcv strains: The XcvT group includes strains that are pathogenic on tomato; the XcvP group includes strains

Corresponding author: Jeffrey B. Jones; Telephone: 1-352-392-7244; E-mail: jbj@gnv.ifas.ufl.edu

Florida Agricultural Experiment Station, Journal Series No. R-07193.

Nucleotide and/or amino acid sequence data can be found at the GenBank data base as accession no. AF190120. that are pathogenic on pepper; and the XcvTP group includes strains that are pathogenic on both plant species (Minsavage et al. 1990). On tomato, three races, designated T1, T2, and T3, have been identified based on their reaction on three tomato cultivars: Hawaii 7998 (H7998), Hawaii 7981 (H7981), and Bonny Best (Jones et al. 1998, 1995; Stall 1995). T1 strains carrying the avirulence gene avrRxv only induce hypersensitive reactions (HRs) on the genotype H7998 (Whalen et al. 1993) and T2 strains do not induce an HR on any of the indicator cultivars, while T3 strains carry the gene $a v r X v 3$ and induce an HR on the tomato genotype H7981 and all pepper cultivars tested (Minsavage et al. 1996). In addition, the ability of T1 and T2 strains to cause HR on pepper (nonhost resistance) is controlled by a different avr gene designated avrBsT (Minsavage et al. 1990).

Three tomato genotypes with high levels of resistance to race $\mathrm{T} 3$ of the bacterial spot pathogen were found by Scott et al. (1995). However, the resistance found in Lycopersicon pimpinellifolium PI 128216 and PI 126932 and L. esculentum cv. H7981 appears to be controlled by the interaction of the same two genes, $a v r X v 3$ and $X v 3$ (Minsavage et al. 1996; Scott et al. 1995).

The role of Avr proteins in plant-pathogen interactions has been one of the most interesting aspects. Currently, only a few of these gene products have been associated with a biochemical function such as enzymatic activity, increased fitness, induction of host-specific symptoms, or transcription activation activity (Duan et al. 1999; Kearney and Staskawicz 1990; Swords et al. 1996; Zhu et al. 1998). Based on recent evidence, Avr proteins are suggested to be delivered by a bacterial delivery system capable of introducing Avr proteins into plant cells (Hyun-Han et al. 1998; Rossier et al. 1999; Van den Ackerveken et al. 1996).

Studies on virulence mechanisms of gram-negative, mammalian pathogens revealed the existence of a novel secretion system now known as the type III protein secretion pathway (Hueck 1998). In plant-pathogenic bacteria, a cluster of genes known as hypersensitivity and pathogenicity ( $h r p)$ genes have been found to be involved in regulating both compatible and incompatible interactions (Bonas 1994). Sequence similarity of at least nine hrp genes with components of the type III secretion pathway described in mammalian pathogens first indicated the 
possibility that hrp genes could be involved in the secretion of a broad range of virulence factors, elicitors, and perhaps even Avr proteins. Evidence for hrp-dependent secretion of Avr proteins has recently been presented for AvrB, AvrPto, AvrBs3, and AvrRxv (Hyun-Han et al. 1998; Rossier et al. 1999).

The objective of this work was to characterize the new avirulence gene $a v r X v 3$ from $\mathrm{Xcv}$ race $\mathrm{T} 3$ involved in specifying resistance in L. pimpinellifolium PI 128216 and PI 126932 and L. esculentum cv. H7981. An attempt was made to study the functional domains of this $a v r$ gene product and their involvement in eliciting the HR in tomato.

\section{RESULTS}

\section{Cloning of the avirulence gene avrXv3.}

To clone the gene responsible for avirulence activity, a total of 500 clones from a genomic DNA library of Xcv T3 strain 91-118 were mobilized into Xcv strain $87-13$ by conjugation. In inoculation tests, one transconjugant, carrying the cosmid clone designated pT3-176, caused an HR in pepper and tomato. Cosmid pT3-176 contained a 35-kb insert of Xcv DNA. Subcloning of the $35-\mathrm{kb}$ insert into pUFR051 yielded a $1.5-\mathrm{kb}$ active subclone, designated pT3-5, capable of eliciting an HR when mobilized into $\mathrm{Xcv}$ and inoculated into resistant host plants. Insert DNA from the active subclone was subsequently moved into plasmid vector pLAFR6 for transposon mutagenesis and pBluescript KS for sequencing.

\section{DNA sequence analysis.}

Sequence analysis of the subclone pT3-5 containing the putative $a v r X v 3$ revealed a single open reading frame (ORF) of $654 \mathrm{bp}$ encoding a 218 amino acid (aa) protein of $24.5 \mathrm{kDa}$ (GenBank accession number AF190120). An imperfect plantinducible promoter (PIP-box) sequence motif (Fenselau and Bonas 1995) was found $66 \mathrm{bp}$ upstream of the putative translational start site. When genomic DNA from several strains of Xcv was hybridized with an internal fragment of $a v r X v 3$, only T3 strains exhibited a positive hybridization signal (Fig. 1).

A sequence homology search of $a v r X v 3$ and its predicted protein did not yield any significant homology to any known

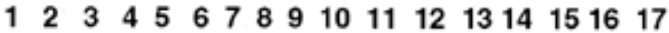

$29 \mathrm{~kb}$

$9 \mathrm{~kb}$

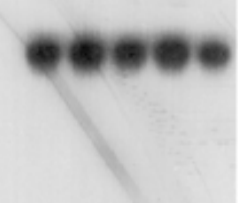

Fig. 1. Southern hybridization analysis of different strains of Xanthomonas campestris pv. vesicatoria. Genomic DNA was digested with EcoRI, immobilized on a membrane, and hybridized to an avrXv3specific probe. $(\lambda)$ Lambda DNA digested with HindIII: Lane 1, XV153, T1strain, phenotypic group A; Lane 2, XV155, T1 strain, phenotypic group A; Lane 3, XV157; T1 strain, phenotypic group A; Lane 4, XV330, T1 strain, phenotypic group A1; Lane 5, XV338, T1 strain, phenotypic group A1; Lane 6, XV1085, T1 strain, phenotypic group A1; Lane 7, XV56, T2 strain; Lane 8, XV141, T2 strain; Lane 9, XV144, T2 strain; Lane 10, XV1111, T2 strain; Lane 11, BV5-4a, T2 strain; Lane 12, MME, T2 strain; Lane 13, XV938, T3 strain; Lane 14, XV1220, T3 strain; Lane 15, XV1484, T3 strain; Lane 16, 91-118, T3 strain; Lane 17. 97-2, T3 strain. gene or protein. Analysis of the predicted protein sequence indicated clustering of amino acids with similar hydrophobic properties and charge (Fig. 2).

\section{Mutagenesis of $a v r X v 3$.}

The regions spanning the three most prominent clusters of hydrophobic and charged residues in AvrXv3 were chosen as targets for deletion (Fig. 2). The predicted AvrXv3 protein is mostly hydrophilic and positively charged; however, the $\mathrm{C}$ terminus is negatively charged.

Polymerase chain reaction (PCR)-based deletion mutagenesis yielded three different mutant proteins lacking 47 aa (MutA), 49 aa (MutB), and 52 aa (MutC) at the $\mathrm{N}$ terminus, middle portion, and $\mathrm{C}$ terminus of the predicted AvrXv3 protein, respectively. Addition of histidine (His) tags at either the $\mathrm{C}$ or $\mathrm{N}$ terminus of the AvrXv3 protein yielded two larger proteins of about $27 \mathrm{kDa}$ (data not shown). The sequence of all mutants was confirmed by sequence analysis.

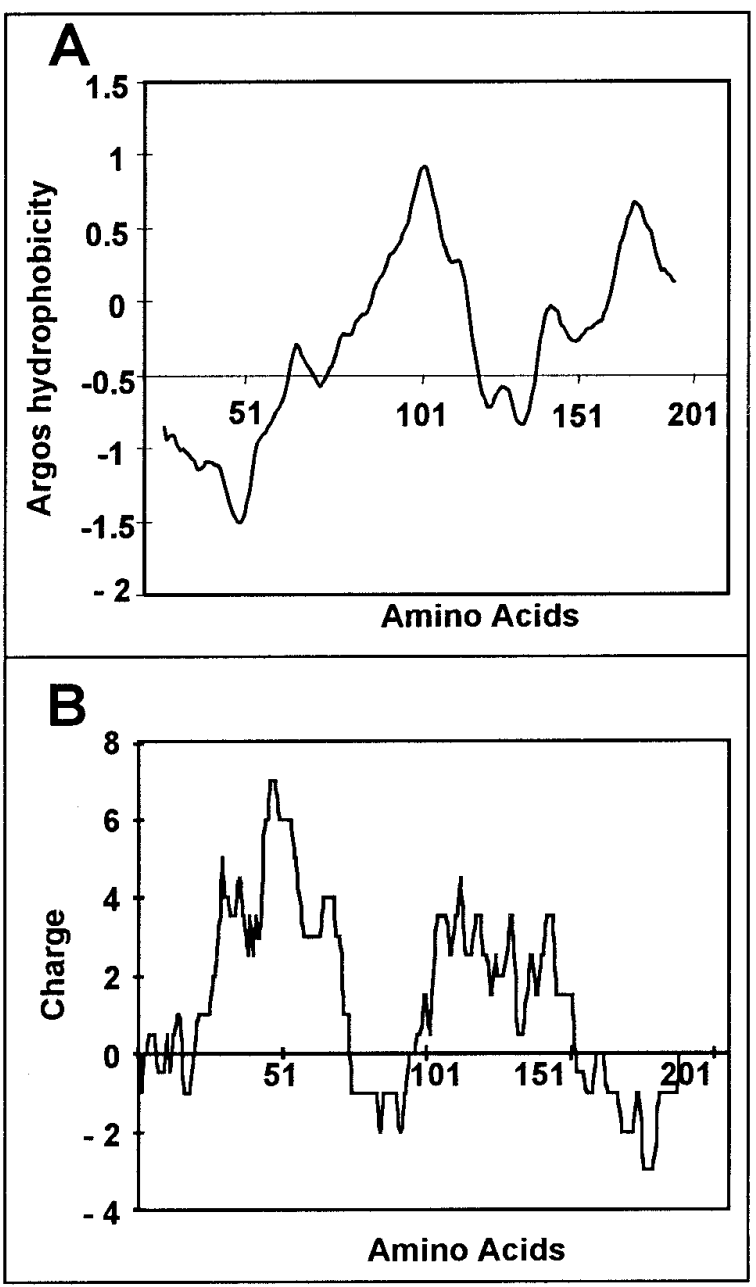

Fig. 2. A, Distribution of hydrophobic residues in predicted protein of $a v r X v 3$. Argos hydrophobicity values were calculated as described by Shaw (1995). Solid line: average of hydrophobicity values for 20 amino acid residues. B, Distribution of charged residues in predicted protein of avrXv3. Charge values were calculated as described by Shaw (1995). Solid line: average of charge values for 20 amino acid residues. 
To test the avirulence activity of the $a v r X v 3$ alleles, the three deletion mutants, the wild-type gene, and the His-tagged constructs were cloned into pLAFR6, and introduced into the virulent strain of Xcv ME-90 (Bonas et al. 1991). Even though all modified genes were under control of their natural promoter, only the wild-type construct of $a v r X v 3$ conferred on this strain the ability to elicit the HR in the resistant tomato NIL 216 (Table 1).

Clone pT3-5 encompassing avrXv3 was also mutagenized with Tn3-uidA. Sixteen of 300 transconjugants carrying transposon derivatives were unable to elicit the HR when inoculated into tomato NIL 216 and pepper cv. Early Calwonder. The relative position and orientation of six Tn3-uidA insertions were determined by restriction endonuclease digestion analysis (data not shown). A preliminary screening for the presence of $\beta$-glucuronidase (GUS) activity in the transconjugants grown in NYG or XVM2 broth revealed activity only in mutant derivatives designated 144, 245, and 249 (data not shown). Tn3-uidA derivative pT3-5::249 was sequenced. The uidA gene was fused in frame 277 nucleotides downstream of the putative translational start of the $a v r X v 3$ protein. Xcv transconjugants carrying pT3-5::249 were used for in planta and media protein expression studies.

Growth experiments and electrolyte leakage (Fig. 3A and B) in plants showed that the virulent Xcv strain 93-1 became avirulent (HR) when the clone pT3-5 was introduced by conjugation. Marker exchange mutagenesis of Xcv T3 strain 91118 with pT3-5::249 resulted in the generation of the mutant ME24, fully virulent on the tomato NIL 216. Growth of ME24 on pepper cv. Early Calwonder resembled more that of the avirulent T3 strain than that of the virulent strain (Fig. 3A). However, electrolyte leakage data indicated that the marker exchange mutant had lost its ability to elicit the typical HR on pepper cv. Early Calwonder (Fig. 3B).

\section{Expression of the avrXv3 gene.}

The ORF of $a v r X v 3$ was cloned into the expression vector pET-15b. IPTG induction of transformed cells of Escherichia

Table 1. Comparison of activity of wilt-type $a v r X v 3$ and its mutant alleles in avirulence activity assays, Agrobacterium tumefaciens-mediated transient expression, and transcription activation activity in yeast

\begin{tabular}{|c|c|c|c|c|c|}
\hline \multirow[b]{2}{*}{ Constructs } & \multicolumn{2}{|c|}{$\begin{array}{l}\text { HR activity } \\
\text { in tomatow }\end{array}$} & \multicolumn{2}{|c|}{$\begin{array}{l}\text { HR by transient ex- } \\
\text { pression in tomato }\end{array}$} & \multirow{2}{*}{$\begin{array}{c}\text { Transcription } \\
\text { activation } \\
\text { activity } \\
\text { in yeast }^{\mathbf{y}}\end{array}$} \\
\hline & $\begin{array}{l}\text { NIL } \\
216\end{array}$ & $\begin{array}{l}\text { Fla. } \\
7060\end{array}$ & $\begin{array}{l}\text { NIL } \\
216\end{array}$ & $\begin{array}{l}\text { Fla. } \\
7060\end{array}$ & \\
\hline AvrXv3 & + & - & + & - & $21.29 \pm 0.08 b$ \\
\hline MutA & - & - & - & - & $0.05 \mathrm{~b}$ \\
\hline MutB & - & - & - & - & $22.59 \pm 0.08 b$ \\
\hline MutC & - & - & - & - & $5.41 \pm 0.01 \mathrm{~d}$ \\
\hline HisT3 & - & - & + & - & $28.55 \pm 0.02 \mathrm{a}$ \\
\hline $\mathrm{T} 3 \mathrm{His}$ & - & - & + & - & $31.41 \pm 0.06 \mathrm{a}$ \\
\hline $\mathrm{RF}$ & $\mathrm{NA}^{\mathrm{z}}$ & NA & NA & NA & $10.30 \pm 0.1 \mathrm{c}$ \\
\hline $\mathrm{P}$ & NA & NA & NA & NA & $10.14 \pm 0.04 \mathrm{c}$ \\
\hline
\end{tabular}

${ }^{\mathrm{w}} \mathrm{HR}=$ hypersensitive response. $\mathrm{NIL}=$ near-isogenic line. Constructs were introduced into the virulent Xanthomonas campestris pv. vesicatoria $(\mathrm{Xcv})$ strain ME-90 under control of their original promoter.

${ }^{x}$ Constructs were introduced into Agrobacterium tumefaciens $\mathrm{C} 58 \mathrm{C} 1$ under control of the $35 \mathrm{~S}$ promoter.

${ }^{y}$ Constructs were introduced into yeast strain EGY48 under control of a yeast constitutive promoter. $\beta$-Galactosidase activity \pm 1 standard error is expressed in Miller units. Different letters next to each number indicate statistically significant differences by Duncan test $(\alpha=0.05)$.

${ }^{z}$ Not applicable. coli strain BL21 (DE3) pLysS carrying the fusion clone resulted in production of a fusion protein of expected size (data not shown).

A chicken polyclonal antibody was raised against the putative AvrXv3 protein. Initial efforts to detect production of the $a v r X v 3$ protein in Xcv strains were complicated by the presence of many nonspecific bands on Western blots (immunoblots) when purified total IgY extracts were used as primary antiserum (data not shown). This antiserum was affinitypurified to avoid the problem of nonspecific bands. Affinitypurified antibody detected AvrXv3 and AvrXv3-His fusion proteins of expected sizes expressed in Xcv strain 93-1 transconjugants and E. coli, respectively (data not shown).

GUS activity of $\mathrm{Xcv}$ transconjugants carrying various uidA fusion constructs was determined in media and in planta induction experiments. Results indicated that $a v r X v 3$ is strongly induced in the pepper cultivars Early Calwonder (ECW) and ECW30R, and the tomato cultivars Fla. 7060 and NIL 216 (Fig. 4A), as well as in XVM2 broth (Fig. 4B). The level of

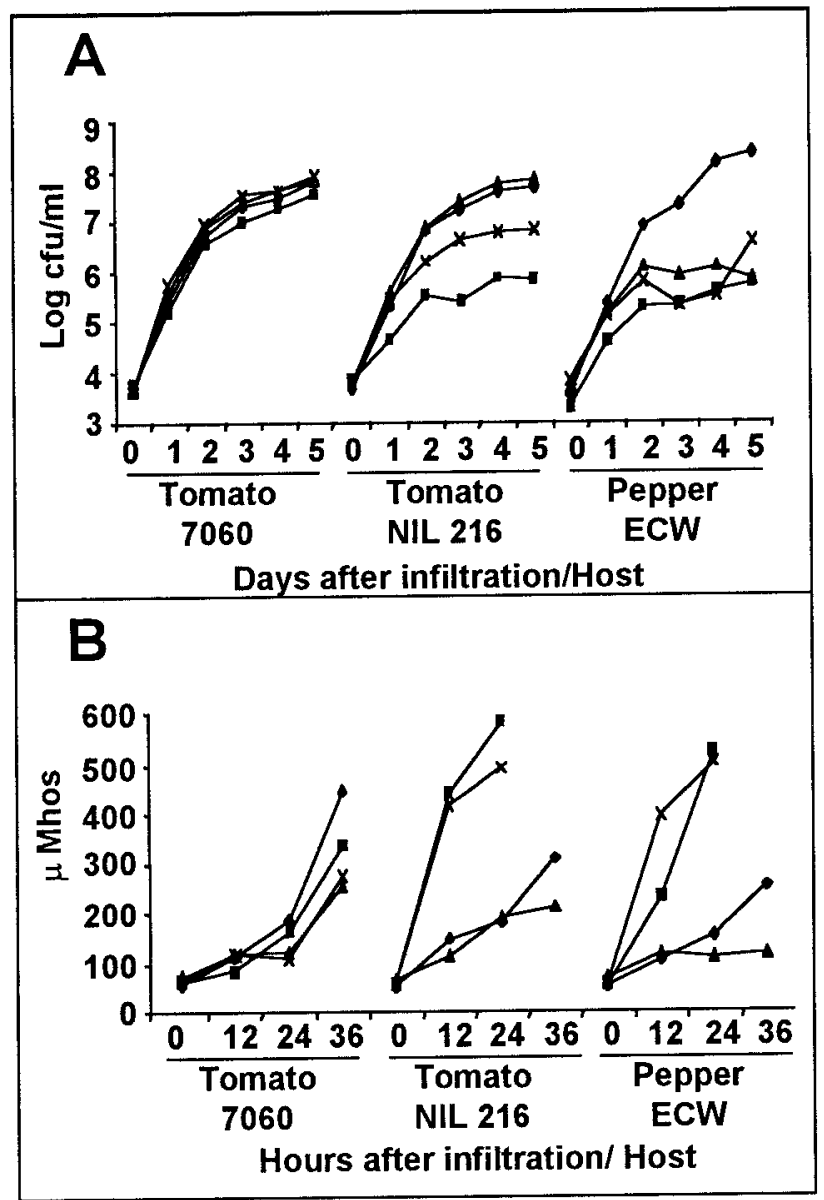

Fig. 3. A, Growth of Xanthomonas campestris pv. vesicatoria wild-type and mutant strain transconjugants infiltrated at $10^{5} \mathrm{CFU}$ per ml into leaves of tomato (genotypes Fla. 7060 and NIL 216) and pepper cv. Early Calwonder, and incubated at $28^{\circ} \mathrm{C}$. B, Electrolyte leakage from tomato (genotypes Fla. 7060 and NIL 216) and pepper cv. Early Calwonder after infiltration of leaves with $X$. campestris pv. vesicatoria wild-type and mutant strain transconjugants at $10^{8} \mathrm{CFU}$ per $\mathrm{ml}$ and incubation at $28^{\circ} \mathrm{C}$. Transconjugants used were pUFR051::93-1 virulent T2 (- -), pT3-5::93-1 avirulent T2 carrying avrXv3 (-口-), pUFR051:: ME24 virulent T3 (-A-), and pUFR051::91-118 avirulent T3 (-x-). 
GUS activity was comparable to the level exhibited by transconjugants expressing uidA constitutively behind the lac $Z$ promoter. In planta, induction of the $a v r X v 3$ gene occurred within $5 \mathrm{~h}$ post inoculation and GUS activity was similar to or higher than the level detected in transconjugants carrying pUXV1006::61 (avrBs3-uidA fusion) $25 \mathrm{~h}$ post inoculation.

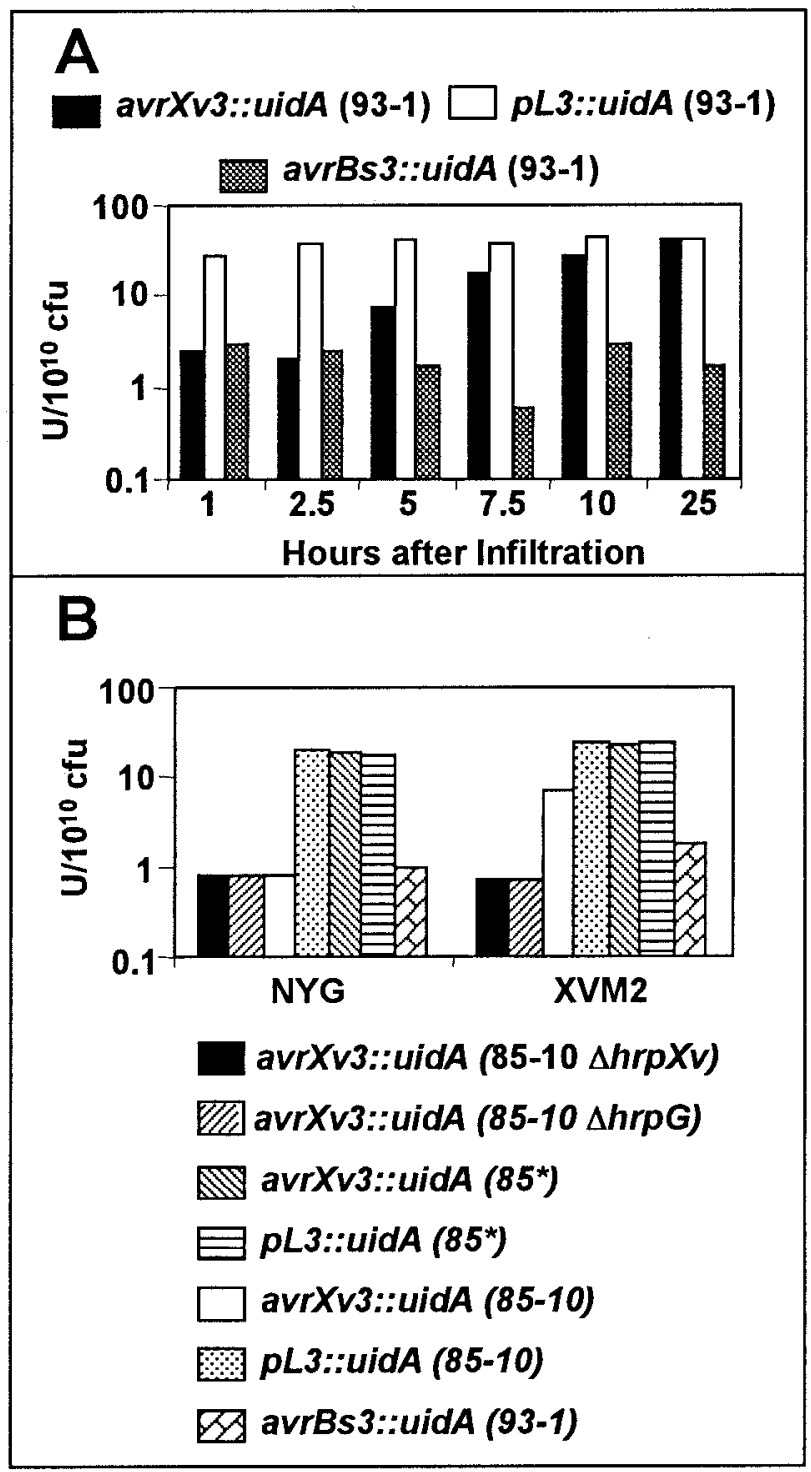

Fig. 4. A, Activity of $\beta$-glucuronidase (GUS) expressed in Xanthomonas campestris pv. vesicatoria $(\mathrm{Xcv})$ transconjugants grown in the tomato near-isogenic line (NIL) 216. Transconjugants of the virulent Xcv strain 93-1 carrying translational fusions pT3-5::249 (avrXv3::uidA), pUXV1006::61 (avrBs3::uidA), and plasmid-borne GUS gene under control of lacZ promoter (pL3::uidA) were infiltrated into tomato NIL 216. GUS activity is reported as $\mathrm{U}$ per $10^{10} \mathrm{CFU}$ (nanomoles methylumbelliferone $\left[\mathrm{MU}\right.$ ] produced per min per $10^{10} \mathrm{CFU}$ ). The same trend was observed with pepper cvs. Early Calwonder (ECW) and ECW30R, and tomato genotype Fla. 7060. B, GUS activity expressed in Xcv transconjugants grown in different media. Bacteria were grown at $28^{\circ} \mathrm{C}$ with shaking for $18 \mathrm{~h}$ in NYG (Daniels et al., 1984) or XVM2 (Wengelnik et al. 1996a) broth. pT3-5::249 (avrXv3::uidA) in Xcv 85-10 $\Delta h r p X v$, pT35::249 (avrXv3::uidA) in Xcv 85-10 $\Delta$ hrpG, pT3-5::249 (avrXv3::uidA) in Xcv $85^{*}$, GUS gene under control of lacZ promoter (pL3::uidA) in Xcv 85*, pT3-5::249 (avrXv3::uidA) in 85-10, pL3::uidA in 85-10, and pUXV1006::61 (avrBs3::uidA) in Xcv 93-1.
When the same GUS fusion constructs were introduced into $\mathrm{Xcv}$ strain $85^{*}$ expressing a constitutively active $h r p G$ gene (Wengelnik et al. 1999), a high level of GUS expression was observed for the $a v r X v 3$ construct (Fig. 4B). In contrast, when GUS fusion constructs were introduced into the mutant $\mathrm{XcV}$ strains 85-10 $\Delta h r p X v$ and 85-10 $\Delta h r p G$, which are unable to express $h r p X$ and $h r p G$ (Wengelnik and Bonas 1996; Wengelnik et al. 1996b), respectively, only a low level of GUS activity was detected (Fig. 4B).

\section{$a v r X v 3$ induces the HR when expressed} inside the plant cell.

Agrobacterium tumefaciens-mediated expression of avrXv3 inside plant cells led to HR in the resistant tomato NIL 216, but not in the susceptible Fla. 7060, $48 \mathrm{~h}$ after inoculation (Table 1). The confluent necrosis observed in the resistant genotype as a result of transient expression resembles the HR induced by race $\mathrm{T} 3$ of $\mathrm{Xcv}$ expressing $a v r X v 3$. Furthermore, HR in the resistant tomato NIL 216 only occurred when the $35 \mathrm{~S}$ promoter controlled the expression of $a v r X v 3$. A. tumefaciens carrying the empty binary vector pMD-1 did not induce the development of any reaction on either NIL 216 or Fla. 7060. When mutated constructs of $a v r X v 3$ were introduced into the plant cells by A. tumefaciens-mediated transient expression, only the HisT3 and T3His mutants were able to elicit the HR (Table 1).

AvrXv3 has putative transcription activation activity.

Wild type and the mutated forms of $a v r X v 3$ fused to the LexA DNA binding domain were expressed in the yeast strain EGY48. The transcription activation activity of each construct was determined by measurement of $\beta$-galactosidase activity. AvrXv3 exhibited significant transcription activation activity, compared with the negative controls, the homeodomain of the Drosophila protein Bicoid (RF), and the plasmid pEG202 (P) without the insert (Table 1).

Deletion of acidic regions located at the $\mathrm{N}$ terminus and middle portion of the AvrXv3 protein did not alter its transcription activation activity. However, the deletion of 52 aa at the $\mathrm{C}$ terminus of MutC made this mutant unable to induce transcription of the $\beta$-galactosidase reporter gene. The addition of His tags to either end of the AvrXv3 protein did not alter its transcription activation activity (Table 1).

\section{DISCUSSION}

A gene-for-gene system has been identified involving T3 strains of Xcv, three different cultivars of tomato, and all cultivars of pepper tested (Minsavage et al. 1996). We cloned and characterized the avr gene involved in the interaction and designated it avrXv3. Southern hybridization analysis indicates that this $a v r$ gene is limited to T3 strains.

Bacterial growth and electrolyte leakage experiments in planta indicated that mobilization of the active $a v r$ gene into a previously virulent strain resulted in a lower growth rate of the bacterium in the resistant tomato and pepper genotypes. This limited growth was most likely due to the onset of the HR, as has also been reported for other Xcv strains carrying avr genes, such as avrRxv (Whalen et al. 1993). Interestingly, when $a v r X v 3$ was mutated by marker exchange in the original strain 91-118, bacterial growth in pepper was not restored to the fully compatible level as in tomato NIL 216. This may in- 
dicate the presence of at least one additional pepper-specific $a v r$ gene or contribution of $a v r X v 3$ to virulence of strain 91118 in pepper.

When electrolyte leakage was measured, the speed and degree of damage caused by the transconjugants carrying the intact gene and the wild-type T3 strain were equally high due to rapid cell death caused by the incompatible interaction between $a v r X v 3$ and $X v 3$. Furthermore, the onset of electrolyte leakage induced by avirulent strains correlated with the onset of the visible HR ( $24 \mathrm{~h})$. This finding agrees with observations made of other gene-for-gene interactions involving other races of Xcv (Minsavage et al. 1990; Whalen et al. 1993). Conversely, the speed and amount of damage caused by the virulent strains were characteristically reduced in the compatible interactions. These results indicate that $a v r X v 3$ alone was able to restrict growth of Xcv strain 93-1 and induce the HR in resistant plants.

The monocistronic nature observed in the $a v r X v 3$ gene agrees with what has been found for the majority of $a v r$ genes described so far (Leach and White 1996). A PIP-box upstream of the start codon of $a v r X v 3$ resembles that described for the $h r p B$ and other pathogenicity operons of Xcv (Fenselau and Bonas 1995). However, previous studies on the role of this element in the expression of the avrRxv gene from Xcv indicated that the PIP-box was not essential for its activity (Ciesiolka et al. 1999). In $a v r X v 3$, the PIP-box may be involved in the regulation of gene expression once the bacterium is inside the plant. Analysis of $a v r X v 3-u i d A$ fusions indicated that the expression of $a v r X v 3$ was strongly induced in tomato, pepper, and the medium XVM2, which is known to mimic the intercellular space of plant cells (Wengelnik et al. 1996a). In addition, constitutive expression of GUS in transconjugants of the Xcv strain $85^{*}$ (Wengelnik et al. 1999) carrying the $a v r X v 3$-uidA fusion and a mutated form of $h r p G$ suggested that expression of $a v r X v 3$ is controlled by the hrp gene regulatory system. Furthermore, the lack of induction of GUS expression observed in the mutant Xcv strains 85-10 $\Delta h r p G$ and 85-10 $\Delta h r p X v$ carrying the avrXv3-uidA fusion indicated that $h r p X v$ is necessary for the activation of transcription of $a v r X v 3$. These results are the first report of a plant-inducible $a v r$ gene found in a plant-pathogenic bacterium. The direct role of the PIP-box in the expression of $a v r X v 3$ still remains to be confirmed.

In this study, A. tumefaciens-mediated transient expression of $a v r X v 3$ indicated that the gene product must be present inside the host cell to trigger the HR. These results agree with what has been shown for several other Avr proteins (Bonas and Van den Ackerveken 1997; de Feyter et al. 1998; Duan et al. 1999; Gopalan et al. 1996; Leister et al. 1996; Parker and Coleman 1997; Scofield et al. 1996; Tang et al. 1996; Van den Ackerveken et al. 1996).

The clustering of negative residues in a particular region of a protein along with interspersed hydrophobic amino acids could be associated with domains involved in activation of transcription (Goodrich et al. 1996; Ptashne and Gann 1997). Experiments designed to compare the ability of different deletion mutants to activate transcription in yeast indicated that the $\mathrm{C}$ terminus of AvrXv3 encoded an active transcription activation domain. The presence of a transcription activation domain at the $\mathrm{C}$ terminus of the AvrXv3 protein draws a parallel with previous reports on similar findings in the AvrXa10 protein (Zhu et al. 1998). However, in contrast to AvrXa10, nuclear localization signals (NLSs) are absent in the AvrXv3 protein, and a lack of correlation between transcription activation and avirulence was observed with mutant alleles of AvrXv3. The inability of MutA and MutB to cause HR in tomato may be explained by the disruption of potential DNAbinding or protein-binding domains required for avirulence. On the other hand, the small size of the AvrXv3 protein and its potential ability to diffuse into the nucleus may explain the lack of an NLS.

Tagging of bacterial avr genes has been commonly used to monitor protein expression and secretion. The short, synthetic epitope tag known as FLAG has been successfully used to construct C-terminal fusions with several Avr proteins such as AvrB, AvrPto, AvrRxv, AvrXa10, and AvrBs3 without causing any apparent alterations in their secretion or avirulence activity (Gopalan et al. 1996; Rossier et al. 1999; Van den Ackerveken et al. 1996; Young et al. 1994). Addition of the His tags at either terminus of the AvrXv3 protein did not alter its ability to elicit the HR in tomato, assessed by transient expression, or to activate transcription in yeast. However, when either construct was introduced into a virulent strain of Xcv, the resulting transconjugants were unable to elicit the HR in the resistant host. These results may indicate that modifications of the termini could be interfering with the secretion of AvrXv3 either by modifying an unknown signal for secretion recognized by the Hrp system or by altering the threedimensional structure of the protein needed for secretion. It is also important to mention that the His tags used in this work contained six histidine residues flanked by stretches of 4 aa and 33 aa (pET-15b), or six histine residues preceded by 44 aa (pET-22b). Therefore, the higher complexity and length of the His tag, compared with the FLAG, could explain why secretion was inhibited when the His tag was used.

\section{MATERIALS AND METHODS}

\section{Bacterial strains, plasmids, and media.}

The bacterial strains and plasmids used in this study are listed in Table 2. Strains of $\mathrm{Xcv}$ were grown at $28^{\circ} \mathrm{C}$ on plates of nutrient agar (BBL; Becton Dickinson and Company, Cockeysville, MD) or in nutrient broth for plant inoculations. Strains of E. coli were routinely cultivated at $37^{\circ} \mathrm{C}$ on LuriaBertani (LB) medium (Maniatis et al. 1982). Plasmids were introduced into E. coli by transformation (Maniatis et al. 1982) and mobilized into Xanthomonas strains by conjugation with pRK2073 as the helper plasmid in triparental matings (Ditta et al. 1980; Figurski and Helinski 1979). Triparental matings were made at $28^{\circ} \mathrm{C}$ on plates of NYG agar (Daniels et al. 1984). Xanthomonas spp. transconjugants were grown at $28^{\circ} \mathrm{C}$ in nutrient, NYG, or XVM2 broth (Wengelnik et al. 1996a) for gene induction and protein expression experiments. Antibiotics were added to the media at the following final concentrations: ampicillin, $100 \mu \mathrm{g} / \mathrm{ml}$; kanamycin, 25 or 50 $\mu \mathrm{g} / \mathrm{ml}$; rifamycin SV, $100 \mu \mathrm{g} / \mathrm{ml}$; spectinomycin, $50 \mu \mathrm{g} / \mathrm{ml}$; and tetracycline, $12.5 \mu \mathrm{g} / \mathrm{ml}$.

\section{Plant material and plant inoculations.}

Seeds of pepper (Capsicum annuum) cv. Early Calwonder and NIL ECW30R, tomato cvs. Fla. 7060, NIL 216, and H7998 were planted in Plugmix (W. R. Grace \& Co., Cam- 
bridge, MA). After 2 weeks, the emerged seedlings were transferred to Metromix 300 (W. R. Grace \& Co.) in 10-cm plastic pots. Seedlings were grown in the greenhouse at temperatures ranging from 25 to $35^{\circ} \mathrm{C}$ (night/day). Tomato plants were grown for 4 to 5 weeks and then the terminal bud was removed above the fully expanded sixth true leaves. Plants were inoculated approximately 7 days after topping and transferred to a growth room kept at a constant temperature of either 25 or $28^{\circ} \mathrm{C}$ with a daily 16-h light period.

Bacterial cultures for plant inoculations were grown in nutrient broth for $18 \mathrm{~h}$ at $28^{\circ} \mathrm{C}$ with shaking (100 rpm; KS10; BEA-Enprotech, Hyde Park, MA). Cells were pelleted by centrifugation $(4,000 \times g, 15 \mathrm{~min})$ and resuspended in sterile tap water. For electrolyte leakage in pepper and tomato, the concentration of cells was adjusted to an $\mathrm{OD}_{600}=0.3(2-5 \times$
$10^{8}$ CFU per ml) with a spectrophotometer (Spectronic 20; Spectronic-UNICAM, Rochester, NY). Bacterial suspensions were diluted to a concentration of $2-5 \times 10^{5} \mathrm{CFU}$ per $\mathrm{ml}$ in sterile tap water for population dynamics studies. Leaves of pepper and tomato were infiltrated with a hypodermic syringe and needle as previously described (Hibberd et al. 1987).

\section{Molecular genetic techniques.}

Standard molecular techniques were used for the extraction of genomic and plasmid DNA, restriction endonuclease digestions of DNA, cloning procedures, and Southern blot hybridization analyses (Ausubel et al. 1992; Maniatis et al. 1982). Enzymes for restriction digestion and ligation reactions were purchased from Promega (Madison, WI) and used following the manufacturer's protocol. For Southern hybridiza-

Table 2. Bacterial strains, plasmid vectors, and plasmid constructs used in this study

\begin{tabular}{|c|c|c|}
\hline Designation & Relevant characteristics & Source or reference \\
\hline $\begin{array}{l}\text { Xanthomonas campestris pv. vesicatoria } \\
\text { 91-118 } \\
97-2 \\
87-13,93-1 \\
\text { ME24 } \\
85-10 \\
85^{*} \\
85-10 \Delta h r p G \\
85-10 \Delta h r p X v \\
\text { ME-90 }\end{array}$ & $\begin{array}{l}\text { Tomato race 3, } \operatorname{Rif}^{\mathrm{r}}, a v r X v 3^{+} \\
\text {Tomato race 3, } a v r X v 3^{+} \\
\text {Tomato race } 1, \mathrm{Rif}^{\mathrm{r}} \\
\text { 91-118 marker exchange, } a v r X v 3 \text { mutant } \\
\text { Pepper race } 2 \text {, tomato race 1, Rif } \\
\text { 85-10, E44K exchange mutant, } h r p G^{\mathrm{r}}, \mathrm{Rif}^{\mathrm{r}} \\
\text { 85-10 deleted for } h r p G, \mathrm{Rif}^{\mathrm{r}} \\
\text { 85-10 deleted for } h r p X v, \mathrm{Rif}^{\mathrm{r}} \\
\text { 85-10 carrying Tn5, } \mathrm{Rif}^{\mathrm{r}} \mathrm{Km}^{\mathrm{r}}\end{array}$ & $\begin{array}{l}\text { This study } \\
\text { This study } \\
\text { This study } \\
\text { This study } \\
\text { Minsavage et al. } 1990 \\
\text { Wengelnik et al. } 1999 \\
\text { Wengelnik et al. 1996b } \\
\text { Wengelnik and Bonas } 1996 \\
\text { Bonas et al. } 1991\end{array}$ \\
\hline $\begin{array}{l}\text { XV153, XV155, XV157 } \\
\text { XV330, XV338, XV1085 } \\
\text { 56, 141, 144, 1111, BV5-4a, MME } \\
\text { XV938, XV1220, XV1484 }\end{array}$ & $\begin{array}{l}\text { Tomato race 1, phenotypic group A, } a v r X v 3 \text { absent } \\
\text { Tomato race 1, phenotypic group A1, avrXv3 absent } \\
\text { Tomato race } 2, \text { avrXv3 absent } \\
\text { Tomato race } 3, a v r X v 3^{+}\end{array}$ & \\
\hline $\begin{array}{l}\text { X. gardneri } \\
\text { XG444, XG451, XCGA2 }\end{array}$ & avrXv3 mutant & \\
\hline $\begin{array}{l}\text { Saccharomyces cerevisiae } \\
\text { EGY48 }\end{array}$ & MAT $\alpha, \operatorname{trp} 1$, his3, ura3, 6ops-LEU2 & R. Brent ${ }^{\mathrm{y}}$ \\
\hline $\begin{array}{l}\text { Agrobacterium tumefaciens } \\
\text { C58C1 }\end{array}$ & Carrying pGV2260, Rif $^{\mathrm{r}}$ & B. Staskawicz z \\
\hline $\begin{array}{l}\text { Escherichia coli } \\
\text { DH5 } \alpha \\
\text { C2110 } \\
\text { HB101 } \\
\text { BL21(DE3)pLysS }\end{array}$ & $\begin{array}{l}\mathrm{F}^{-} \text {recA } \phi 80 \mathrm{~d} \text { lacZ } \mathrm{M} \mathrm{M} 15 \\
\mathrm{Nal}^{\mathrm{r}} \text { polA mutant } \\
\mathrm{F}^{-} \text {recA } \\
\text { Host strain for } \mathrm{pET}-15 \mathrm{~b}\end{array}$ & $\begin{array}{l}\text { Bethesda Research Laboratories, Gaithersburg, MD } \\
\text { Stachel et al. } 1985 \\
\text { Boyer and Roulland-Dussoix } 1969 \\
\text { Novagen, Madison, WI }\end{array}$ \\
\hline $\begin{array}{l}\text { Plasmids } \\
\text { pLAFR3 } \\
\text { pL3uidA } \\
\text { pLAFR6 } \\
\text { pUFR051 } \\
\text { pBluescript II KS +/- } \\
\text { pET15-b } \\
\text { pET15-b24 } \\
\text { pRK2073 } \\
\text { pHoKmGUS } \\
\text { pSShe } \\
\text { pUXV1006::61, ::74 } \\
\text { pT3-176 } \\
\text { pT3-5 } \\
\text { pT3-5::24, ::47, ::144, ::221, ::245, ::249 } \\
\text { pMD-1 } \\
\text { pEG202 } \\
\text { pMW106 } \\
\text { pRFHM1 } \\
\text { pSH17-4 }\end{array}$ & 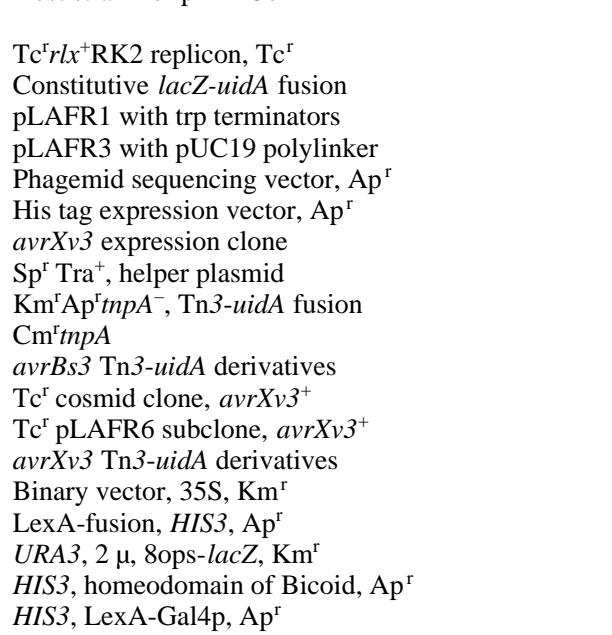 & $\begin{array}{l}\text { Staskawicz et al. } 1987 \\
\text { B. Staskawicz } \\
\text { B. Staskawicz } \\
\text { de Feyter and Gabriel } 1991 \\
\text { Stratagene, La Jolla, CA } \\
\text { Novagen, Madison, WI } \\
\text { This study } \\
\text { Figurski and Helinski } 1979 \\
\text { B. Staskawicz } \\
\text { Stachel et al. 1985 } \\
\text { Bonas et al. } 1989 \\
\text { This study } \\
\text { This study } \\
\text { This study } \\
\text { B. Staskawicz } \\
\text { R. Brent } \\
\text { R. Brent } \\
\text { R. Brent } \\
\text { R. Brent }\end{array}$ \\
\hline
\end{tabular}

${ }^{y}$ Department of Molecular Biology, Massachusetts General Hospital, Boston.

${ }^{z}$ Department of Plant Biology, University of California, Berkeley. 
tions, DNA probes were labeled with $\alpha^{32} \mathrm{P}$ with the Random Primed DNA Labeling kit (Boehringer Mannheim, Indianapolis, IN) and probed against the DNA immobilized on a Biodyne nylon membrane (Life Technologies, Grand Island, NY).

A total genomic DNA library of Xcv strain 91-118 (tomato race 3) was constructed in the cosmid vector pLAFR3 as previously described (Minsavage et al. 1990). Individual clones were mobilized into Xcv strain $87-13$ or $93-1$ by triparental mating (Ditta et al. 1980; Figurski and Helinski 1979) and transconjugants were inoculated into pepper and tomato to screen for elicitation of an HR.

The cosmid pT3-176 containing a 35-kb insert of Xcv DNA was selected for further manipulation. A 5.5-kb BamHI-EcoRI DNA fragment from pT3-176 was subcloned into pBluescript $\mathrm{KS}+/-$ (Stratagene, La Jolla, CA) for further analysis. Deletion subclones were generated by restriction digestion of the pBluescript clone with XhoI, SalI, or ClaI (one flanking site for each within the polylinker), removal of excised fragments, and self-ligation (recircularization) of the remaining vectorinsert DNA. Various fragments were subcloned into pUFR051 to assess the HR-inducing activity in Xcv. The smallest active subclone generated by ClaI deletion (2.2-kb insert) was further subcloned by digestion with PstI and subsequent recircularization of the plasmid. The insert DNA was cloned into pBluescript for sequencing, and also into pLAFR6 for Tn3uidA insertional mutagenesis tests. The pLAFR6 clone, designated pT3-5, elicited an HR when mobilized into Xcv and inoculated into resistant host plants.

\section{DNA sequence analysis.}

Sequencing of both strands of a 1,524-bp (pT3-5) DNA fragment encompassing $a v r X v 3$ was initiated with pBluescript vector T3 and T7 primers. Sequencing was done at the ICBR sequencing facility (University of Florida, Gainesville, FL) with the Applied Biosystems (Foster City, CA) model 373 system. To complete sequencing, custom primers were synthesized at the ICBR facility with an Applied Biosystems model 394 DNA synthesizer. The computer program SeqAid II version 3.81 was used to analyze nucleotide sequence data and predicted protein products.

The analysis of distribution of hydrophobic and charged residues throughout the predicted AvrXv3 protein was carried out as described by Shaw (1995). A search for homology of the nucleotide sequence of $a v r X v 3$ and the amino acid sequence of the predicted AvrXv3 was carried out on the World Wide Web with the BLAST 2.0 algorithm (Altschul et al. 1997).

Tn3-uidA insertion sites were sequenced with an oligonucleotide primer complementary to the $\mathrm{N}$ terminus of the GUS gene (Jefferson et al. 1987, 5'GATTTCACGGGTTGGGGT TTCT3').

\section{Protein expression in E. coli.}

Custom oligonucleotide primers were synthesized, RST88 (5'CCGC TCGAGATGACAAGTAGTATCAATC3') and RST89 (5'CCGCTCGAGCTACTTAACGAGATTTGTTA C3'), which allowed amplification of a DNA fragment containing the 654-bp ORF of $a v r X v 3$ from Xcv target DNA by the PCR. PCR amplification of DNA was done in a DNA thermocycler (M. J. Research, Watertown, MA) with Taq
DNA polymerase (Promega, Madison, WI). Each 50- $\mu$ l PCR contained $1 \times$ amplification buffer (from the manufacturer), $100 \mu \mathrm{M}$ concentrations of each dNTP, $17.5 \mu \mathrm{M}$ concentrations each primer, $1.5 \mathrm{mM} \mathrm{MgCl}, 1.25 \mathrm{U}$ of Taq DNA polymerase, and $100 \mathrm{ng}$ of template DNA. For this particular primer pair, each cycle consisted of $30 \mathrm{~s}$ of denaturation at $95^{\circ} \mathrm{C}, 30 \mathrm{~s}$ of annealing at $56^{\circ} \mathrm{C}$, and $1 \mathrm{~min}$ of extension at $72^{\circ} \mathrm{C}$. An initial cycle with an annealing temperature of $48^{\circ} \mathrm{C}$ was also added. For the final cycle, the extension step was prolonged to $5 \mathrm{~min}$. Restriction endonuclease $\mathrm{XhoI}$ sites were incorporated into the primer sequences to facilitate cloning of the gene in-frame into the expression region of plasmid vector pET-15b. PCR products were treated with proteinase $\mathrm{K}$ and cleaned as previously described (Crowe et al. 1991) prior to digestion with XhoI for cloning into the fusion vector.

The fusion plasmid pET15-b24 was transformed into E. coli host BL21 (DE3) pLysS and sequenced to confirm that the correct fusion had been generated. Fusion protein was expressed in E. coli at $37^{\circ} \mathrm{C}$ for 3 to $5 \mathrm{~h}$ after induction of early log phase cultures by the addition of $0.1 \mathrm{mM}$ IPTG (isopropyl $\beta$-thiogalactopyranoside). Fusion protein was affinity purified from French-pressed cell suspensions (30 $\mathrm{ml}$ of 4-h induced culture) in the presence of urea $(6 \mathrm{M})$ and phenylmethylsulfonyl fluoride $(0.5 \mathrm{mM})$ with the His-Bind Resin and Buffer Kit (Novagen, Madison, WI) following the manufacturer's protocol. Protein extracts were desalted with Microcon 100 microconcentrator spin columns (Amicon, Beverly, MA) and stored at $-70^{\circ} \mathrm{C}$ in $10 \mathrm{mM}$ phosphate-buffered saline (PBS, $\mathrm{pH}$ 7.2).

Protein concentrations were measured with BioRad protein assay dye reagent (BioRad Laboratories, Hercules, CA). Recovery of fusion protein was verified by solubilization in Laemmli buffer (Maniatis et al. 1982), boiling for $5 \mathrm{~min}$. and running on $12 \%$ discontinuous sodium dodecyl sulfatepolyacrylamide ready-gels (BioRad Laboratories). For analytical protein analyses, E. coli or Xanthomonas cells were harvested by centrifugation, washed once in sterile, distilled water, and solubilized in Laemmli buffer. Gels were stained in Coomassie blue R-250 or transferred to polyvinylidene difluoride (PVDF) membranes (BioRad Laboratories) for Western blot analysis with a BioRad Mini Trans-blot chamber according to the manufacturer's protocol.

\section{Preparation of antisera and immunoblotting.}

The AvrXv3 fusion protein purified from E. coli was used for immunization of chickens for polyclonal antibody (IgY) production. Two 6- to 8-month-old laying Leghorn hens were injected subcutaneously along the wing vein and in one footpad with $100 \mu \mathrm{l}$ of purified protein in PBS at a concentration of $100 \mu \mathrm{g} / \mathrm{ml}$. Additional injections were made after 2 and 12 weeks to boost specific antibody titer. Eggs were collected daily, marked for identification, and stored at $4{ }^{\circ} \mathrm{C}$ until a period of 2 weeks after the final immunization. Peak titers of $1 / 1,000$ were detected in eggs of the immunized hens approximately 9 days post-immunization as determined in enzyme-linked immunosorbent assays (ELISAs; data not shown).

Initially, crude IgY extracts were prepared from every third egg by dispersing the yolks in 4 volumes of $0.1 \mathrm{M}$ phosphate buffer at pH 7.6 (Polson et al. 1985). Sample dilutions of $1 / 100$ and $1 / 1,000$ were used as the primary antisera in indi- 
rect ELISAs to identify peak antibody titers. Briefly, wells of MicroFluor B microtiter plates were coated with $100 \mu \mathrm{l}$ of purified fusion protein $(1 \mu \mathrm{l} / \mathrm{ml}$ in coating buffer) by incubation at $4^{\circ} \mathrm{C}$ overnight. The wells were washed $4 \times 125 \mu \mathrm{l}$ with PBST (PBS buffer with 0.05\% Tween 20). Dilutions of the crude yolk extracts $(100 \mu \mathrm{l})$ were added to each well and the plates were incubated for $2 \mathrm{~h}$ at room temperature. Wells were washed $4 \times 125 \mu \mathrm{l}$ with PBST and then $100 \mu \mathrm{l}$ of $1 / 1,000 \mathrm{di}-$ luted anti-chicken IgG-alkaline phosphatase conjugate (Sigma Chemical, St. Louis, MO) was added. Plates were incubated at room temperature for $2 \mathrm{~h}$ and the wells were then washed $4 \times$ $125 \mu \mathrm{l}$ with PBST before $100 \mu \mathrm{l}$ of substrate solution (4methylumbelliferyl phosphate $0.33 \mathrm{mg} / \mathrm{ml}$, MUP, Sigma Chemical Company) was added. Fluorescence in the wells was measured after incubation of the plates for $30 \mathrm{~min}$ at room temperature.

IgY was purified from individual eggs selected from high titer (peak) sample times by polyethylene glycol precipitation as previously described (Polson et al. 1985) or by the commercially available EGGstract IgY Purification System (Promega, Madison, WI). Titer of individual eggs was determined by ELISA and one preparation was selected for use in immunoblot assays. The anti-fusion antiserum was affinity purified to the fusion protein immobilized on nitrocellulose (Smith and Fisher 1984) and antibodies recovered in the $\mathrm{pH}$ 2.3 eluate were used for immunoblot tests at a dilution of $1 / 100$ relative to the original purified extract.

Western blot analysis was carried out as described by Maniatis et al. (1982). Blots were reacted for $20 \mathrm{~h}$ at $4^{\circ} \mathrm{C}$ with primary $\mathrm{IgY}$ antiserum and bound antibody was detected with anti-chicken IgG-alkaline phosphatase conjugate and 4nitroblue tetrazolium chloride and 5-bromo-4-chloro-3-indolyl phosphate (NBT/BCIP) substrate tablets (Boehringer Mannheim, Indiana, IN).

\section{Mutagenesis of $a v r X v 3$.}

Insertion mutagenesis was performed with Tn3-uidA as previously described (Bonas et al. 1989). Individual insertion derivatives were analyzed by restriction enzyme digestion profiles and mobilized into Xcv strain 93-1 for HR tests in plants. Selected insertion derivatives were used to generate marker exchange gene replacement mutants in the wild-type Xcv strain 91-118 as described by Bonas et al. (1991).

The positions of insertions in derivatives selected for protein expression experiments were confirmed by sequencing. GUS (UidA) activity was determined in Xcv transconjugants after growth in NYG or XVM2 broth and in leaves of pepper and tomato by measurement of fluorescence with 4-methylumbelliferyl $\beta$-D-glucuronide as substrate (MUG; Sigma Chemical Company) as previously described (Schulte and Bonas 1992; Wengelnik and Bonas 1996).

Samples of Xcv grown in plant tissue for various lengths of time were obtained by macerating an area of $1 \mathrm{~cm}^{2}$ of inoculated leaf tissue in $1 \mathrm{ml}$ of sterile tap water. An aliquot of 500 $\mu \mathrm{l}$ of the macerated tissue suspension was centrifuged for 2 min at $12,000 \times g$ in a microcentrifuge tube to pellet bacterial cells. The pellets were resuspended in $50 \mu \mathrm{l}$ of sterile, distilled water and frozen at $-70^{\circ} \mathrm{C}$ until all samples from all time points were accumulated. The samples were then thawed quickly and $450 \mu \mathrm{l}$ of MUG extraction buffer (Jefferson 1987; Jefferson et al. 1987) was added to each tube. Reactions were incubated at $37^{\circ} \mathrm{C}$ and terminated at regular time intervals with $0.2 \mathrm{M} \mathrm{Na}_{2} \mathrm{CO}_{3}$. Fluorescence was measured with a Cytoflor II fluorescence multi-well plate reader (PerSeptive Biosystems, Framingham, MA) calibrated against known standard concentrations of methyl-umbelliferone (MU; Sigma Chemical Company). MicroFluor B flat bottom microtiter plates (Dynatech Laboratories, Chantilly, VA) were used.

Appropriate dilutions of plant extracts and broth cultures were plated onto media to determine the CFU of bacteria to calculate UidA activity as units per CFU value. This value was calculated based on the number of nanomoles of MU produced per minute per CFU of bacteria.

PCR-based deletion mutagenesis was performed on the clone pT3-5 to create in-frame deletions of approximately 50 aa in three different sites along the sequence of this gene. This clone carries the entire ORF of $a v r X v 3$ and its original promoter region. First, pT3-5 was digested with HindIII and EcoRI and the fragment containing the promoter region and the ORF of a $v r X v 3$ was transferred to pBluescript KS, resulting in pBS:T3 $\Delta$ Pst. The targets for deletion were chosen by identifying putative domains defined by the distribution of hydrophobic and charged residues in the predicted protein (Fig. 2). A set of eight oligonucleotide primers was synthesized at the ICBR DNA Synthesis Laboratory (University of Florida, Gainesville) to make the in-frame deletions of the three putative domains (Table 3). Separate PCRs were carried out with pBS:T3 $\Delta$ Pst as template and the following primer combinations: P1/P2, P3/P8, P1/P4, P5/P8, P1/P6, and P7/P8. To ease the process of screening for the right construct, unique restriction sites for the endonucleases XhoI, AvaI, and KpnI were engineered as silent mutations in primers P3, P5, and P7, respectively (Table 3). PCR was carried out as described above. The annealing temperature used for all primers was $60^{\circ} \mathrm{C}$.

Subsequently, PCR products were diluted 100-fold and an aliquot of $2 \mu \mathrm{l}$ of each product was combined as follows: $\mathrm{P} 1 / \mathrm{P} 2+\mathrm{P} 3 / \mathrm{P} 8, \mathrm{P} 1 / \mathrm{P} 4+\mathrm{P} 5 / \mathrm{P} 8$, and P1/P6 + P7/P8. The mixtures were used as templates for a second PCR with the primers P1/P8 and the same conditions described above. The resulting modified constructs were designated $m u t A, m u t B$, and $m u t C$. These mutants were digested with HindIII and EcoRI and cloned into pLAFR6.

To determine the effect of possible changes in the threedimensional structure of the AvrXv3 on its activity, the termini of the predicted protein were also modified by the addition of six His residues. First, the ORF of $a v r X v 3$ was cloned into $\mathrm{pET} 15 \mathrm{~b}$ as described before. The resulting construct was designated pET15b:HisT3. Secondly, primers P1 and RST88b (5'CCGCTCGAGCTTCTTAACGAGATTTGTTAC3'), which eliminate the stop codon of the gene, were used to isolate the ORF of $a v r X v 3$ and its original promoter from pBS:T3 3 Pst. The resulting fragment was digested with HindIII and XhoI and cloned into pET22b, in frame with an His tag at the $3^{\prime}$ end of the ORF. This construct was designated pET22b:T3His. PCR was carried out as described before. All mutants were sequenced at the ICBR sequencing facility.

\section{Avirulence activity in Xcv background.}

The constructs pLAFR6:mutA, pLAFR6:mutB, and pLAFR6: $m u t C$ were introduced into the virulent $\mathrm{Xcv}$ strain ME-90 by triparental mating and inoculated into the tomato 
Table 3. Sequence of specific oligonucleotides used for polymerase chain reaction-based deletion mutagenesis of $a v r X v 3^{z}$

\begin{tabular}{|c|c|c|}
\hline ID & Oligonucleotide sequence & Restriction enzyme site added \\
\hline $\mathrm{P} 1$ & 5'GCGCGCAATTAACCCTCACTAAAG3' & - \\
\hline P2 & 5'GTAACGATTGATACTACTTGTCATGG3' & - \\
\hline P3 & 5'GACAAGTAGTATCAATCGTTCGCTCGAGTGGAGCAGGTCG3' & XhoI \\
\hline P4 & 5'AACGCCCTTGATCGGCTTATTTCG3' & - \\
\hline P5 & 5'ATAAGCCGATCAAGGGCGTTGTTATGCCCGAGAATCGC3' & AvaI \\
\hline P6 & 5’TTTAGCGGCATACCCCTGCGAACG3' & - \\
\hline P7 & 5'CGCAGGGGTATGCCGCTAAAGAAAAGGGTACCGTAAGG3' & KpnI \\
\hline P8 & 5'CG CGCGTAATACGACTCACTATAG3' & - \\
\hline
\end{tabular}

${ }^{\mathrm{z}}$ Restriction sites added by each oligonucleotide are also indicated.

NILs 216 and Fla. 7060 as described above. To generate pLAFR6:T3His, pET22b:T3His was digested with HindIII and PstI and the insert was cloned into pLAFR3. The construct HisT3 was cloned into a previously constructed plasmid, pLAFR3:Pt3, under control of the original promoter region of $a v r X v 3$. The resulting constructs, pLAFR3:T3His and pLAFR3Pt3:HisT3, were introduced into Xcv strain ME-90 by triparental mating and inoculated into the tomato NILs 216 and Fla. 7060 as described above.

\section{A. tumefaciens-mediated transient expression.}

The binary vector pMD-1, kindly provided by B. Staskawicz, was used for all $A$. tumefaciens-mediated transient expression assays. The ORFs of $a v r X v 3$, mutA, mutB, and mutC were isolated by PCR with the primers RST89b $\left(5^{\prime} \mathrm{CC}\right.$ GTCTAGAATGACAAGTAGTATCAATC3') and RST88c (5'CCGGGATCCCTTCTTAACGAGATTTGTTAC3'), which add the restriction sites $X b a \mathrm{I}$ upstream of the start codon and BamHI downstream of the stop codon, respectively. Following digestion with the appropriate enzyme combination, constructs were cloned into pMD-1. The ORF of $a v r X v 3$ was also cloned into the binary vector pO4541, which lacks the $35 \mathrm{~S}$ promoter. HisT3 was isolated from pET15b:HisT3 by PCR with the primers HIST3-F (5'CCGGAATTCATGGGCAGCA GCCATCAT3') and RST88c, which add EcoRI and BamHI sites, respectively. T3His was isolated from pET22b:T3His by PCR with the primers RST89c (5'CCGGAATTCATGACAA GTAGTATCAATC3') and T3HIS-R (5'GCTGGATCCAG TTATTGCTCAGCGG3'), which add EcoRI and BamHI sites, respectively. Following digestion with the appropriate enzyme combination, constructs were cloned into pMD-1. All constructs were maintained in E. coli and transferred to A. tumefaciens by triparental mating as described before.

The A. tumefaciens strain C58C1 containing the Ti-plasmid pGV2260 (Deblaere et al. 1985) and individual transconjugants were grown overnight at $28^{\circ} \mathrm{C}$ in YEB medium (Kapila et al. 1997) amended with $10 \mathrm{mM} \mathrm{N}$-morpholino-ethanesulfonic acid (MES) pH 5.6 (Sigma Chemical Company), 20 $\mu \mathrm{M}$ acetosyringone (Sigma Chemical Company), and the appropriate antibiotics. After overnight growth, the concentration was adjusted to an $A_{600}=0.5-0.6$, bacteria were pelleted, washed with MMA medium pH 5.6 (Murashige and Skoog's medium, Gibco BRL, amended with $10 \mathrm{mM}$ MES, sucrose 20 $\mathrm{g} /$ liter, and $200 \mu \mathrm{M}$ acetosyringone) and resuspended in the same medium to a final concentration of $A_{600}=0.05$. Bacterial suspensions were kept at $25^{\circ} \mathrm{C}$ for $1 \mathrm{~h}$ and then used for infiltration. Fully expanded leaves of the tomato cultivar Fla. 7060 and NIL 216 were infiltrated with the bacterial suspension as described before. After infiltration, plants were incubated at $22^{\circ} \mathrm{C}$ under continuous light for $48 \mathrm{~h}$ or until symptoms developed. Unless otherwise indicated, inoculations were done three times.

\section{Transcription activation activity.}

The yeast strain EGY48 (Saccharomyces cerevisiae) carrying the plasmid pMW106, which contains the lacZ gene under control of LexA-regulated promoters, was used for testing transcription activation activity. The vector pEG202, containing the LexA DNA binding domain sequence under control of the constitutive yeast $\mathrm{ADH} 1$ promoter and a polylinker region at the $\mathrm{C}$ terminus, was used for generating fusions with the wild type and modified AvrXv3 proteins. The ORF of all mutant genes was isolated by PCR with the following primer combinations: mutB and mutC with RST89c/RST88, mutA with RST89c/RST88c, HisT3 with HIST3-F/RST88c, and T3His with RST89c/T3HIS-R. The plasmids pMW106 and pEG202 were maintained in yeast by selection for uracil and His auxotrophy, respectively, and in E. coli by selection for resistance to ampicillin and kanamycin, respectively. The plasmid pSH17-4 carrying the LexA fused to Gal4p activation domain was used as a positive control for transcription activation, and pRFHM1 carrying the non-activating fusion between LexA and the Drosophila protein Bicoid was used as negative control for transcription activation.

Expression of the expected fusion proteins in yeast was determined by standard Western blot analysis (Ausubel et al. 1992) with a polyclonal antibody raised against the LexA DNA-binding domain (kindly provided by E. Golemis). The membranes were reacted for $1 \mathrm{~h}$ at $25^{\circ} \mathrm{C}$ with primary AntiLexA polyclonal antiserum followed by $1 \mathrm{~h}$ of incubation with the anti-rabbit IgG-alkaline phosphatase conjugate (Sigma Chemical Company). Bound antibody was detected with NBT/BCIP substrate tablets (Boehringer Mannheim, Indianapolis, IN). Methods for yeast manipulations were as described by Golemis and Brent (1997). $\beta$-Galactosidase activity assays were performed as described by Clontech Laboratories (Palo Alto, CA). Roger Brent (Department of Molecular Biology, Massachusetts General Hospital, Boston), kindly provided all plasmids and yeast strains used in this study. Unless otherwise indicated, all experiments were arranged in a completely randomized design with three replications. All experiments were done twice. Statistical analysis was conducted with the Statistical Analysis System (SAS Institute, Cary, NC).

\section{LITERATURE CITED}

Altschul, S. F., Madden, T. L., Schäffer, A. A., Zhang, J., Zhang, Z., Miller, W., and Lipman, D. J. 1997. Gapped BLAST and PSI-BLAST: 
A new generation of protein database search programs. Nucleic Acids Res. 25:3389-3402.

Ausubel, F. M., Brent, R., Kingston, R. E., Moore, D. D., Seidman, J. G., Smith, J. A., and Struhl, K., eds. 1992. Current Protocols in Molecular Biology. John Wiley \& Sons, New York.

Bent, A. 1996. Function meets structure in the study of plant disease resistance genes. Plant Cell 8:1757-1771.

Bonas, U. 1994. hrp genes of phytopathogenic bacteria. Curr. Top. Microbiol. Immunol. 192:79-98.

Bonas, U., Schulte, R., Fenselau, S., Minsavage, G. V., Staskawicz, B. J., and Stall, R. E. 1991. Isolation of a gene cluster from Xanthomonas campestris pv. vesicatoria that determines pathogenicity and the hypersensitive response on pepper and tomato. Mol. PlantMicrobe Interact. 4:81-88.

Bonas, U., Stall, R. E., and Staskawicz, B. J. 1989. Genetic and structural characterization of the avirulence gene avrBs3 from Xanthomonas campestris pv. vesicatoria. Mol. Gen. Genet. 218:127-136.

Bonas, U., and Van den Ackerveken, G. 1997. Recognition of bacterial avirulence proteins occurs inside the plant cell: A general phenomenon in resistance to bacterial diseases? Plant J. 12: 1-7.

Boyer, H. W., and Roulland-Dussoix, D. 1969. A complementation analysis of the restriction and modification of DNA in Escherichia coli. J. Mol. Biol. 41:459-472.

Ciesiolka, L. D., Hwin, T., Gearlds, J. D., Minsavage, G. V., Saenz, R., Bravo, M., Handley, V., Conover, S. M., Zhang, H., Caporgno, J., Phengrasamy, N. B., Toms, A. O., Stall, R. E., and Whalen, M. C. 1999. Regulation of expression of avirulence gene $a v r R x v$ and identification of a family of host interaction factors by sequence analysis of avrBsT. Mol. Plant-Microbe Interact. 12:35-44.

Crowe, J. S., Cooper, H. J., Smith, M. A., Sims, M.. J., Parker, D., and Gewert, D. 1991. Improved cloning efficiency of polymerase chain reaction (PCR) products after proteinase K digestion. Nucleic Acids Res. 19:184.

Daniels, M. J., Barber, C. E., Turner, P. C., Sawczyc, M. K., Byrde, R. J. W., and Fielding, A. H. 1984. Cloning of genes involved in pathogenicity of Xanthomonas campestris pv. campestris using the broad host range cosmid pLAFR1. EMBO J. 3:3323-3328.

de Feyter, R., and Gabriel, D. W. 1991. Use of cloned DNA methylase genes to increase the frequency of transfer of foreign genes into Xanthomonas campestris pv. malvacearum. J. Bacteriol. 173:6421-6427.

de Feyter, R., McFadden, H., and Dennis, L. 1998. Five avirulence genes from Xanthomonas campestris pv. malvacearum cause genotype-specific cell death when expressed transiently in cotton. Mol Plant-Microbe Interact. 11:698-701.

Deblaere, R., Bytebier, B., De Greve, H., Deboeck, F., Schell, J., Van Montagu, M., and Leemans, J. 1985. Efficient octopine Ti plasmidderived vectors for Agrobacterium-mediated gene transfer to plants. Nucleic Acids Res. 13:4777-4788.

Ditta, G., Stanfield, S., Corbin, D., and Helinski, D. 1980. Broad host range DNA cloning system for gram-negative bacteria: Construction of a gene bank of Rhizobium meliloti. Proc. Natl. Acad. Sci. USA 77: 7347-7351.

Duan, Y. P., Castañeda, A., Erdos, G., and Gabriel, D. W. 1999. Expression of a single, host-specific, bacterial pathogenicity gene in plant cells elicits division, enlargement, and cell death. Mol. Plant-Microbe Interact. 12: 556-560.

Fenselau, S., and Bonas, U. 1995. Sequence and expression analysis of the $h r p B$ pathogenicity operon of Xanthomonas campestris pv. vesicatoria which encodes eight proteins with similarity to components of the Hrp, Ysc, Spa, and Fli secretion systems. Mol. Plant-Microbe Interact. 8:845-854.

Figurski, D., and Helinski, D. R. 1979. Replication of an origincontaining derivative of plasmid RK2 dependent on a plasmid function provided in trans. Proc. Natl. Acad. Sci. USA 76:1648-1652.

Flor, H. H. 1971. Current status of the gene-for-gene concept. Annu. Rev. Phytopathol. 9:275-296.

Golemis, E. A., and Brent, R. 1997. Searching for interacting proteins with the two-hybrid system III. Pages 43-72 in: The Yeast TwoHybrid System. P. L. Bartel and S. Fields, eds. Oxford University Press, New York.

Goodrich, J. A., Cutler, G., and Tijian, R. 1996. Contacts in context: Promoter specificity and macromolecular interactions in transcription. Cell 84:825-830.

Gopalan, S., Bauer, D. W., Alfano, J. A., Loniello, A. O., He, S. Y., and
Collmer, A. 1996. Expression of the Pseudomonas syringae avirulence protein AvrB in plant cells alleviates its dependence on the hypersensitive response and pathogenicity (Hrp) secretion system in eliciting genotype-specific hypersensitive cell death. Plant Cell 8: 1095-1105.

Hibberd, A. M., Stall, R. E., and Bassett, M. J. 1987. Different phenotypes associated with incompatible races and resistance genes in bacterial spot disease of pepper. Plant Dis. 71:1075-1078.

Hueck, C. J. 1998. Type III protein secretion systems in bacterial pathogens of animals and plants. Microbiol. Mol. Biol. Rev. 62:379-433.

Hyun-Han, J., Bauer, D. W., Fouts, D. E., and Collmer, A. 1998. A cloned Erwinia chrysanthemi Hrp (type III protein secretion system) functions in Escherichia coli to deliver Pseudomonas syringae Avr signals to plant cell and to secrete Avr proteins in culture. Proc. Natl. Acad. Sci. USA 95:10206-10211.

Jefferson, R. A. 1987. Assaying chimeric genes in plants: The GUS gene fusion system. Plant Mol. Biol. Rep. 5:387-405.

Jefferson, R. A., Kavanagh, T. A., and Bevan, M. W. 1987. GUS fusions: $\beta$-Glucuronidase as a sensitive and versatile gene fusion marker in higher plants. EMBO J. 6:3901-3907.

Jones, J. B., Stall, R. E., and Bouzar, H. 1998. Diversity among Xanthomonas pathogenic on pepper and tomato. Annu. Rev. Phytopathol. 36: 41-58.

Jones, J. B., Stall, R. E., Scott, J. W., Somodi, G. C., Bouzar, H., and Hodge, N. C. 1995. A third tomato race of Xanthomonas campestris pv. vesicatoria. Plant Dis. 79:395-398

Kapila, J., De Rycke, R., Van Montagu, M., and Angenon, G. 1997. An Agrobacterium-mediated transient gene expression system for intact leaves. Plant Sci. 122:101-108.

Kearney, B., and Staskawicz, B. J. 1990. Widespread distribution and fitness contribution of Xanthomonas campestris avirulence gene avrBs2. Nature 346:541-543.

Leach, J. E., and White, F. F. 1996. Bacterial avirulence genes. Annu. Rev. Phytopathol. 34: 153-179.

Leister, R. T., Ausubel, F. M., and Katagiri, F. 1996. Molecular recognition of pathogen attack occurs inside the plant cells in plant disease resistance specified by the Arabidopsis gene RPS2 and RPM1. Proc. Natl. Acad. Sci. USA 93:15497-15502.

Maniatis, T. A., Fritsch, E. F., and Sambrook, J. 1982. Molecular Cloning: A Laboratory Manual. Cold Spring Harbor Laboratory, Cold Spring Harbor, NY.

Minsavage, G. V., Dahlbeck, D., Whalen, M. C., Kearney, B., Bonas, U., Staskawicz, B. J., and Stall, R. E. 1990. Gene-for-gene relationships specifying disease resistance in Xanthomonas campestris pv. vesicatoria - pepper interactions. Mol. Plant-Microbe Interact. 3:41-47.

Minsavage, G. V., Jones, J. B., and Stall, R. E. 1996. Cloning and sequencing of an avirulence gene (avrRxv3) isolated from Xanthomonas campestris pv. vesicatoria tomato race 3 . Phytopathology $86: \mathrm{S} 15$ (Abstr.)

Parker, J. E., and Coleman, J. M. 1997. Molecular intimacy between proteins specifying plant-pathogen recognition. TIBS 22:291-296.

Polson, A., Coetzer, T., Kruger, J., von Maltzahn, E., and van der Merwe, K. J. 1985. Improvements in the isolation of IgY from the yolks of eggs laid by immunized hens. Immun. Invest. 14:323-327.

Ptashne, M., and Gann, A. 1997. Transcriptional activation by recruitment. Nature 386:569-577.

Rossier, O., Wengelnik, K., Hahn, K., and Bonas, U. 1999. The Xanthomonas Hrp type III system secretes proteins from plant and mammalian bacterial pathogens. Proc. Natl. Acad. Sci. USA 96:9368-9373.

Schulte, R., and Bonas, U. 1992. Expression of the Xanthomonas campestris pv. vesicatoria hrp gene cluster, which determines pathogenicity and hypersensitivity on pepper and tomato, is plant inducible. J. Bacteriol. 174:815-823.

Scofield, S. R., Tobias, C. M., Rathjen, J. P., Chang, J. H., Lavelle, D. T., Michelmore, R. W., and Staskawicz, B. J. 1996. Molecular basis of gene-for-gene specificity in bacterial speck disease of tomato. Science 274:2063-2065.

Scott, J. W., Jones, J. B., and Somodi, G. C. 1995. Screening tomato accessions for resistance to Xanthomonas campestris pv. vesicatoria, race T3. HortScience 30:579-581.

Shaw, G. 1995. Protein sequence interpretation using a spreadsheet program. BioTechniques 19:978-983.

Smith, D. E., and Fisher, P. A. 1984. Identification, developmental regulation, and response to heat shock of two antigenically related 
forms of a major nuclear envelope protein in Drosophila embryos: Application of an improved method for affinity purification of antibodies using polypeptides immobilized on nitrocellulose blots. J. Cell Biol. 99:20-28.

Stachel, S. E., An, G., Flores, C., and Nester, E. W. 1985. A Tn3 lacZ transposon for the random generation of $\beta$-galactosidase gene fusions: Application to the analysis of gene expression in Agrobacterium. EMBO J. 4:891-898

Stall, R. E. 1995. Xanthomonas campestris pv. vesicatoria. Pages $167-$ 181 in: Pathogenesis and Host Specificity in Plant Diseases: Histopathological, Biochemical, Genetic and Molecular Bases. U. S. Singh, R. P. Singh, and K. Kohmoto, eds. Elsevier Science, New York.

Staskawicz, B. J., Dahlbeck, D., Keen, N., and Napoli, C. 1987. Molecular characterization of cloned avirulence genes from race 0 and race 1 of Pseudomonas syringae pv. glycinea. J. Bacteriol. 169:57895794.

Swords, K. M. M., Dahlbeck, D., Kearney, B., Roy, M., and Staskawicz, B. J. 1996. Spontaneous and induced mutations in a single open reading frame alter both virulence and avirulence in Xanthomonas campestris pv. vesicatoria avrBs2. J. Bacteriol. 178: 4661-4669.

Tang, X., Frederick, R. D., Zhou, J., Halterman, D. A., Jia, Y., and Martin, G. B. 1996. Initiation of plant disease resistance by physical interaction of AvrPto and Pto kinase. Science 274:2060-2063.

Van den Ackerveken, G., Morois, E., and Bonas, U. 1996. Recognition of the bacterial avirulence protein AvrBs3 occurs inside the host plant cell. Cell 87:1307-1316.
Wengelnik, K., and Bonas, U. 1996. HrpXv, an AraC-type regulator, activates expression of five out of six loci in the hrp cluster of Xanthomonas campestris pv. vesicatoria. J. Bacteriol. 178:3462-3469.

Wengelnik, K., Marie, C., Russel, M., and Bonas, U. 1996a. Expression and localization of HrpA1, a protein of Xanthomonas campestris pv. vesicatoria essential for pathogenicity and induction of the hypersensitive reaction. J. Bacteriol. 178:1061-1069.

Wengelnik, K., Rossier, O., and Bonas, U. 1999. Mutations in the regulatory gene hrpG of Xanthomonas campestris pv. vesicatoria result in constitutive expression of all hrp genes. J. Bacteriol. 181:6828-6831.

Wengelnik, K., Van den Ackerveken, G., and Bonas, U. 1996b. HrpG, a key hrp regulatory protein of Xanthomonas campestris pv. vesicatoria is homologous to two-component response regulators. Mol. PlantMicrobe Interact. 9:704-712.

Whalen, M. C., Wang, J. F., Carland, F. M., Heiskell, M. E., Dahlbeck, D., Minsavage, G. V., Jones, J. B., Scott, J. W., Stall, R. E., and Staskawicz, B. J. 1993. Avirulence gene avrRxv from Xanthomonas campestris pv. vesicatoria specifies resistance on tomato line Hawaii 7998. Mol. Plant-Microbe Interact. 6:616-627.

Young, S. A., White, F. F., Hopkins, C. M., and Leach J. E. 1994. AVRXa10 protein is in the cytoplasm of Xanthomonas oryzae pv. oryzae. Mol. Plant-Microbe Interact. 7: 799-804.

Zhu, W., Yang, B., Chittoor, J. M., Johnson, L. B., and White, F. F. 1998. AvrXa10 contains an acidic transcriptional activation domain in the functionally conserved $\mathrm{C}$ terminus. Mol. Plant-Microbe Interact. 11: 824-832. 